\title{
Can role models boost entrepreneurial attitudes?
}

\section{Katharina Fellnhofer* and Kaisu Puumalainen}

Lappeenranta University of Technology, LUT School of Business and Management, P.O. Box 20, 53851 Lappeenranta, Finland Email: katharina.fellnhofer@lut.fi Email: kaisu.puumalainen@lut.fi *Corresponding author

\begin{abstract}
This multi-country study used role models to boost perceptions of entrepreneurial feasibility and desirability. The results of a structural equation model based on a sample comprising 426 individuals who were primarily from Austria, Finland and Greece revealed a significant positive influence on perceived entrepreneurial desirability and feasibility. These findings support the argument for embedding entrepreneurial role models in entrepreneurship education courses to promote entrepreneurial activities. This direction is not only relevant for the academic community but also essential for nascent entrepreneurs, policymakers and society at large.
\end{abstract}

Keywords: entrepreneurship education; entrepreneurial role model; perceived entrepreneurial desirability; perceived entrepreneurial feasibility.

Reference to this paper should be made as follows: Fellnhofer, K. and Puumalainen, K. (2017) 'Can role models boost entrepreneurial attitudes?', Int. J. Entrepreneurship and Innovation Management, Vol. 21, No. 3, pp. $274-290$.

Biographical notes: As Erwin-Schrödinger-Fellow, Katharina Fellnhofer is a Visiting Researcher at the Lappeenranta University of Technology, Finland. She received her PhD in Economic Sciences from the University of Innsbruck, Austria. In addition, she is an Entrepreneur of the Austrian small and medium sized company 'Research and Innovation Management GmbH' which is engaged in interdisciplinary European research and innovation projects.

Kaisu Puumalainen is a Professor in Strategy Research at the School of Business, Lappeenranta University of Technology, Finland. Her primary areas of research interest are innovation, entrepreneurship, strategic orientations and internationalisation. She has published on these issues in Journal of the Academy of Marketing Science, International Journal of Research in Marketing, International Business Review, European Journal of Marketing, and Technovation, among others. 


\section{Introduction}

Both Schumpeter's (1934) as well as Shane and Venkataraman's (2000) entrepreneurial schools of thought state that entrepreneurship contributes to the overall wealth of our society. Consequently, education that encourages entrepreneurial activities provides an essential ingredient for economic growth (EC, 2013). So, in principle, our wide-ranging knowledge of effective and fruitful pedagogical initiatives are key for our society in the long run.

Research dedicated toward entrepreneurship education (EE) is receiving growing attention from business and political communities and society as a whole (Pittaway and Cope, 2007; Albornoz, 2008; Rasmussen, 2011; Lorz et al., 2013). Still, the latest reviews (e.g. Lorz et al. 2013; Mason and Siqueira 2014) and studies (Rideout and Gray, 2013; Bae et al., 2014) highlight inconsistent research results in prior efforts. Some previous academic works concluded that the EE course has a positive effect on the perceived attractiveness of entrepreneurship (e.g., Peterman and Kennedy, 2003; Fayolle et al., 2006; Souitaris et al., 2007), but other researchers (e.g., Oosterbeek et al., 2010) do not share this point of view and discuss a negative impact. A diverse set of different target groups and different applied pedagogical approaches increase this inconsistency in research results (Mwasalwiba, 2010), and a lack of rigor in research designs and applied research methods (Lorz et al. 2013) appears to contribute to this deficiency.

Apart from developing entrepreneurial knowledge through traditional methods such as business planning within an EE context, creating an entrepreneurial identity is also essential for the entrepreneurial life. The development of an entrepreneurial identity can be enabled through the inspiration of relevant peer groups (Falck et al., 2012; Obschonka et al., 2012). Being confronted with real entrepreneurs' careers creates a positive awareness (Essers and Benschop, 2007; Clarke, 2011; Wry et al., 2011). However, researchers have not yet illuminated the effects of entrepreneurial role model's inspiration on individuals' entrepreneurial attitudes.

Some researchers (Bandura, 1986; Schröder and Schmitt-Rodermund, 2006) argue that observing others can affect an individual's career choices and decisions. That being so, it is anticipated that entrepreneurial role models will be perceived as encouraging, with a positive attitudinal impact on those considering becoming entrepreneurs. This assumption is based on several earlier studies, which have discussed the existence of role models but have neglected the influence of role model's inspiration (e.g. Krueger 1993; Matthews and Moser, 1996; Zapkau et al., 2015). Also, based on informal observational education with role models, youth could be encouraged to choose a particular career path (Barling et al., 1998; Krumboltz et al., 1976; Mitchell and Krumboltz, 1984). It seems likely, then, that entrepreneurial role models will affect the perceived desirability and feasibility of an individual becoming an entrepreneur. According to Scherer et al. (1989), the observation of role models enables individuals to learn specific skills, knowledge, and behaviours that are relevant and essential for embarking on a new venture. In particular, earlier findings on human capital (e.g., Holtz-Eakin, 2000; Scherer et al., 1991) indicated that entrepreneurial parents can transfer informal business knowledge to youth. The power of role models can also be illuminated by identification and social learning theory (Gibson, 2004). Identification with role models helps individuals to define their self-concept (Akerlof and Kranton, 2000), and according to social learning theory (Bandura, 1977; 1986), individuals are fascinated by role models who encourage their development (Gibson, 2004). Thus, in this study, the effects of role models for enhancing 
individual perceived entrepreneurial desirability and feasibility are illuminated. So the following research question represents the driving force in this effort: Do role models boost entrepreneurial attitudes and how is that accomplished?

This study is structured as follows. After this introduction, we will outline the theoretical background and develop the hypotheses. Next, we will discuss the research methods and present the results. Finally, we will discuss the practical and theoretical implications and limitations and make additional research recommendations.

\section{Theoretical background and hypotheses development}

Parental role models for entrepreneurs have been intensively discussed (e.g., Chlosta et al., 2012; McDougall et al., 1992), as has the influence of networks (Fernández-Pérez et al., 2016; Lerner et al., 1997) and peer groups (Falck et al., 2012; Giannetti and Simonov, 2009; Koellinger et al., 2007; Nanda and Sørensen, 2010; Stuart and Ding, 2006). Davidsson and Wiklund (1997) reported that the awareness of other entrepreneurs boosts entrepreneurial ambitions. Furthermore, colleagues (Bandura, 1986; Schröder and Schmitt-Rodermund, 2006) argued that observing others can affect an individual's career choices and decisions. Overall, informal observational education with role models shows potential to encourage one to follow a certain career path (Barling et al., 1998; Krumboltz et al., 1976; Mitchell and Krumboltz, 1984). While these research strands suggest an association between available role models and the choice of entrepreneurship as an attractive career path, in-depth relationships between entrepreneurial role models and entrepreneurial attitudes have not yet been studied.

Perceived entrepreneurial desirability means the perceived attractiveness of becoming an entrepreneur and it is based on Ajzen's (1991) attitude and subjective norm variables in his Theory of Planned Behaviour (TPB; Krueger et al., 2000). This variable is affected by a social background influenced by the culture, family members, friends and personal entrepreneurial experience. For instance, if receiving a good education for getting well-paid jobs in a large company is communicated in a cultural surrounding, then entrepreneurship will be observed as a less desirable potential career path. If parents are entrepreneurs, in general, entrepreneurship appears to be more attractive for their children than for children of employed parents (Kuehn, 2008; Saeed et al., 2014). In particular, Saeed et al. (2014) stress the significant positive effects of entrepreneurial parental role models concluding that children of entrepreneurs are twice as likely as other children to become self-employed.

Based on Shapero (1975) and, later, Shapero and Sokol's (1982) intentionality-based process model of the entrepreneurial event, Krueger (1993) found strong support for the idea that entrepreneurial intentions derive from perceived desirability. Similar results have been discussed by later researchers (Guerrero et al., 2008) also in the context of the use of information technology innovations (Moghavvemi and Noor Akma Mohd, 2014). However, Fitzsimmons and Douglas (2011) suggest a typology of nascent entrepreneurs as natural entrepreneurs, accidental entrepreneurs and inevitable entrepreneurs by using a large multi-country sample. Their work might be related to the focal construct considering regional social legitimacy proposed by Kibler et al. (2014). This effort demonstrates and explains how regional social legitimacy influences the perception of the desirability and start-up behaviour. If attitudes are the seed of behaviour to act, then a better view that guides the development of this behaviour becomes crucial. Overall, it 
seems likely, then, that entrepreneurial role models will affect perceived entrepreneurial desirability to become an entrepreneur. Thus, the following hypothesis is proposed:

H1 Entrepreneurial role models have a positive impact on perceived entrepreneurial desirability.

Perceived entrepreneurial feasibility represents the degree of one's competence to found a new venture. This awareness is related to Ajzen's (1991) behavioural control variable because in both an individual assesses the ability to be successful with his or her own business. As a measure of uncertainty, previous entrepreneurial experience and self-confidence in one's skills and abilities to be successful in managing entrepreneurial tasks are related to this belief in feasibility perceptions (Krueger and Brazeal, 1994; Chen et al., 1998; Krueger et al., 2000; Kuehn, 2008). Overall, this study is in line with previous studies highlighting a positive power of EE on perceived entrepreneurial feasibility (e.g. Peterman and Kennedy, 2003; Fayolle et al., 2006; Souitaris et al., 2007). However, Diaz-Garcia et al. (2015) build on Ajzen's TPB (1991) to assess the impact of an EE program using a control-group longitudinal design stressing that the candidates perceived greater barriers in the environment over the long run, therefore dropping the feasibility of entrepreneurship as an attractive career path. Nevertheless, this study follows a positive approach suggesting the following:

H2 Entrepreneurial role models have a positive impact on perceived entrepreneurial feasibility.

Figure 1 illustrates the research model.

Figure 1 Research model

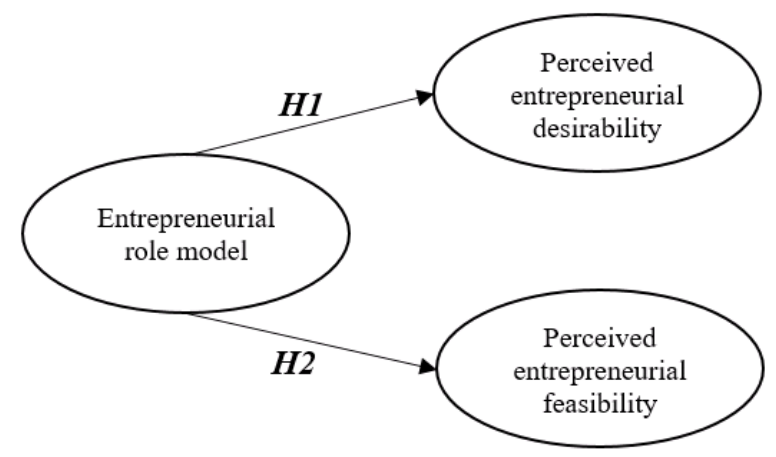

\section{Methods}

\subsection{Research data description}

The sample consisted of 426 participants including 313 participants aged 18-24 years, with $62.68 \%$ male and $37.32 \%$ female. The distribution of nationalities was Austria $(37.56 \%)$, Finland (30.05\%) and Greece $(24.18 \%)$. The data was collected from February 2016 to July 2016 via a questionnaire-based survey online. Table 1 depicts the characteristics of the total sample for this empirical study. 
Table $1 \quad$ Sample

\begin{tabular}{lccc}
\hline Age & Male & Female & Participants \\
\hline$<18$ & 23 & 8 & 31 \\
$18-24$ & 187 & 126 & 313 \\
$25-34$ & 35 & 16 & 51 \\
$35-44$ & 13 & 5 & 18 \\
$45-55$ & 7 & 4 & 11 \\
$56<$ & 2 & 0 & 2 \\
\hline & 267 & 159 & 426 \\
& & & \\
\hline Nationality & Male & Female & 160 \\
\hline Austria & 126 & 34 & 128 \\
Finland & 73 & 55 & 103 \\
Greece & 41 & 62 & 35 \\
other & 27 & 8 & 426 \\
\hline
\end{tabular}

\subsection{Measurement}

In this research study, the risk of common method bias was decreased using the following steps. First, based on the recommendations of Reio (2010) confidentiality and anonymity were guaranteed. Next, this empirical investigation took advantage of well-built scales of past research in EE. The five-item scale for the inspiration of an entrepreneurial role model was modified from Nauta and Kokaly (2001; see Table 5 in the Appendix). Items referring to desirability and feasibility (see Tables 6 and 7 in the Appendix) were taken from Peterman and Kennedy (2003). Participants showed their level of agreement for all items from one indicating strong disagreement to seven indicating strong agreement.

Several reliability and validity tests were implemented following prior recommendations (e.g., Letz and Gerr, 1995; López et al., 2015). Overall, no items had to be omitted. First, a Confirmatory Factor Analysis (CFA) showed an adequate overall model fit (see Table 8 in the Appendix). In this context, all determinants of the correlation matrix of correlating item groups exceeded the threshold of 0.00001 , and all communalities were above 0.5. The Kaiser-Meyer-Olkin (KMO) Test for Sampling Adequacy was applied to show whether items transported enough information (Dziuban and Shirkey, 1974) resulting in values all above 0.5 for all items that indicated adequate reliability according to Kaiser (1974). Next, all Cronbach's alpha values were above 0.784, indicating strong internal consistency (Nunnally, 1978; Hair et al., 1995). Construct validity was significant for all variables $(\mathrm{t}>3.1 ; \mathrm{p}<0.001)$, as illustrated by the standardised factor loadings (Hair et al., 2010). All indicator reliabilities were also sufficient based on the values recommended by Bagozzi and Baumgartner (1994), and composite reliability was satisfactory showing values above 0.6 (Bagozzi (1988). As specified by Fornell and Larcker (1981), average variance extracted (AVE) was adequate with values above 0.5 for all variables. Finally, the CFA results confirmed the reliability of the research instrument. 
Further tests related to construct validity and content validity were performed (Murphy and Davidshofer, 1988; Fraenkel and Wallen, 1993). The results of the bivariate Pearson correlation illustrated in Table 2(a) stressed that all correlations between the variables were significant, confirming that the questionnaire quantified the concept it was intended to measure (Carmines and Zeller, 1990). The variance inflation factor (VIF) was checked for each independent variable. As recommended by Allison (1999) all VIFs were under 2.5. Consequently, multicollinearity was not critical in this work. So the constructs were sufficiently valid and reliable.

\subsection{Control variables}

Control variables such as such as age, gender, nationality and entrepreneurial experience were included in the structural equation modelling (SEM). First of all, Levesque and Minniti (2006) argued that entrepreneurial opportunity costs rise with age. As a consequence, age represented a control variable in our study. Based on the past results of Brush (1992), it was expected that males would tend to be more entrepreneurial. Gender matters when it comes to entrepreneurial initiatives (Fellnhofer et al., 2016). Nationality also represented a controlling variable assuming that the effects in countries in crisis (e.g. Greece) show different effects than in high growth countries (e.g. Finland). Finally, the entrepreneurial experience was also controlled for the assumption that different entrepreneurial experiences effect entrepreneurial perceptions (Fellnhofer and Kraus, 2015).

Table 2(a) Construct means, $S D$, and pearson correlation (bivariate)

\begin{tabular}{|c|c|c|c|c|c|c|c|}
\hline & & Mean & $S D$ & 1 & 2 & 3 & 4 \\
\hline 1 & Inspiration/modelling & 4.02 & 1.31 & 1 & & & \\
\hline 2 & Desirability & 4.47 & 1.49 & $.367 * *$ & 1 & & \\
\hline 3 & Feasibility & 3.66 & 1.16 & $.226 * *$ & $.456^{* *}$ & 1 & \\
\hline 4 & Entrepreneurial experience & 0.45 & 0.25 & $.274 * *$ & $.266^{* *}$ & $.245^{* *}$ & $.274 * *$ \\
\hline
\end{tabular}

Notes: $\mathrm{n}=426{ }^{* *}$ correlation is significant at the 0.01 level (two-tailed).

Table 2(b) Descriptive results for control variables

\begin{tabular}{|c|c|c|c|c|c|c|c|c|}
\hline & & \multirow{2}{*}{$N$} & \multicolumn{2}{|c|}{ Inspiration/modelling } & \multicolumn{2}{|c|}{ Desirability } & \multicolumn{2}{|c|}{ Feasibility } \\
\hline & & & Mean & $S D$ & Mean & $S D$ & Mean & $S D$ \\
\hline \multirow[t]{2}{*}{ Gender } & Males & 267 & 3.99 & 1.37 & 4.58 & 1.44 & 3.86 & 1.19 \\
\hline & Females & 159 & 4.06 & 1.22 & 4.29 & 1.55 & 3.33 & 1.03 \\
\hline \multirow[t]{3}{*}{ Nationality } & Austria & 160 & 3.97 & 1.40 & 4.45 & 1.55 & 3.91 & 1.22 \\
\hline & Finland & 128 & 4.04 & 1.26 & 4.31 & 1.46 & 3.61 & 1.06 \\
\hline & Greece & 103 & 4.07 & 1.22 & 4.66 & 1.38 & 3.25 & 0.94 \\
\hline \multirow[t]{6}{*}{ Age group } & $<18$ & 31 & 3.95 & 1.40 & 4.06 & 1.63 & 3.82 & 1.44 \\
\hline & $18-24$ & 313 & 4.03 & 1.31 & 4.47 & 1.45 & 3.57 & 1.09 \\
\hline & $25-34$ & 51 & 4.09 & 1.13 & 4.67 & 1.43 & 3.91 & 1.23 \\
\hline & $35-44$ & 18 & 3.68 & 1.60 & 4.46 & 1.85 & 3.77 & 1.24 \\
\hline & $45-55$ & 11 & 3.93 & 1.53 & 5.06 & 1.51 & 4.51 & 1.33 \\
\hline & $56<$ & 2 & 3.90 & 1.27 & 3.83 & 2.59 & 4.70 & 2.40 \\
\hline
\end{tabular}




\section{Results}

Tables 2(a) and 2(b) depict construct means, standard deviations $(S D)$ and correlations of the model. All variables correlate significantly.

\subsection{Goodness of fit of the measurement model}

Table 3 confirms the goodness of fit indices for the model. Based on prior studies (e.g. López et al., 2015; Schreiber et al., 2006), the model was tested, and the fit indices are presented in Table 3. Overall, based on the goodness of fit indices, the model can be accepted. The chi-square $\left(\mathrm{X}^{2}\right)$, the goodness of fit index (GFI), comparative fit index (CFI), Tucker-Lewis coefficient (TLI), incremental fit index (IFI) and root mean square error of approximation (RMSEA) exceeded the recommended values. The chi-square value was 656.887 , and chi-square/ $d f$ equalled 1.771 . The chi/square/ $d f$ is below 5.0, which confirms an adequate fit level according to Hair et al. (2010). Furthermore, the GFI was 0.906 for the model indicating an acceptable fit. In line with prior recommendations ( $\mathrm{Hu}$ and Bentler, 1999; Byrne, 1994), CFI values were also above the suggested 0.9 level, to be precise 0.924 for the model. The TLI value with 0.911 for the model was above the recommended value of 0.90 . The IFI value of 0.926 for the model also indicated an acceptable fit based on recommendations (Bentler and Bonett, 1980; Mulaik et al., 1989). Finally, the RMSEA was 0.043 and so less than 0.07 and, thus, measured as adequate based on MacCallum et al. (1996) and Steiger (2007).

Table 3 Summary of goodness of fit indices for the model

\begin{tabular}{lcccccccc}
\hline Fit indices & $X^{2}$ & $p$-value & Chi-square/df & GFI & CFI & TLI & IFI & RMSEA \\
\hline Model & 656.887 & 0.00 & 1.771 & 0.906 & 0.924 & 0.911 & 0.926 & 0.043 \\
Recommended values & $<0.05$ & $<5$ & $>0.90$ & $>0.90$ & $>0.90$ & $>0.90$ & $<0.07$ \\
\hline
\end{tabular}

Notes: $\mathrm{GFI}=$ goodness of fit index, $\mathrm{CFI}=$ comparative fit index, TLI $=$ Tucker Lewis index, IFI $=$ incremental fit index, RMSEA $=$ root mean square residual

\subsection{Structural equation modelling}

Table 4 presents the parameter estimates for the model. In H1, which proposed that entrepreneurial role models have a positive impact on perceived entrepreneurial desirability, a significant standardised regression weight (SRW) of $0.378\left(\mathrm{t}=7.126^{* * *}\right.$, $\mathrm{R}^{2}=0.249$ ) was found. In other words, the results indicated that role models significantly and positively affected one's perceived entrepreneurial desirability. For H2, which proposed that entrepreneurial role models have a positive impact on perceived entrepreneurial feasibility, a less significant SRW of 0.180 was discovered $\left(t=3.322^{* *}\right.$, $\mathrm{R}^{2}=0.260$ ). In short, the effects of the role models on entrepreneurial desirability were stronger than on entrepreneurial feasibility.

As assumed, entrepreneurial experience significantly and positively influenced the effects of role models on both entrepreneurial desirability ( $\mathrm{SRW}=0.174, \mathrm{t}=3.328 * * *$ ) and entrepreneurial feasibility $(\mathrm{SRW}=0.182, \mathrm{t}=3.331 * * *)$. Also, there were gender-related effects in both hypotheses. Males tended to perceive both entrepreneurial feasibility ( $\mathrm{SRW}=0.203, \mathrm{t}=4.005^{* * *}$ ) and entrepreneurial desirability (SRW $=0.133$, $\left.\mathrm{t}=2.756^{* * *}\right)$ significantly higher than females. As indicated in Table 2(b) highlighting 
the gender-related descriptive results, role models were perceived as more important for females than for males even though entrepreneurial desirability and entrepreneurial feasibility were lower for females than for males. This result showed that a role model could play a more important role for females than for males in facilitating entrepreneurial attitudes. Furthermore, Greek participants tended to perceive entrepreneurial feasibility significantly lower than the reference nation Austria ( $\mathrm{SRW}=-0.205, \mathrm{t}=-3.539 * * *)$. Finally, the age group above 56 years perceived entrepreneurial feasibility significantly higher than the other age groups $\left(\mathrm{SRW}=0.214, \mathrm{t}=2.843^{* *}\right)$, which is in line with the significant results related to the entrepreneurial experience.

Table 4 Parameter estimates for the model

\begin{tabular}{|c|c|c|c|}
\hline Parameters standardised $(n=426)$ & $S R W$ & $S E$ & $t$-value $(p)$ \\
\hline H1: Entrepreneurial role model $\rightarrow$ Desirability & 0.378 & 0.062 & $7.126^{* * *}$ \\
\hline \multicolumn{4}{|l|}{ Control variables } \\
\hline Entrepreneurial experience & 0.174 & 0.329 & $3.328 * * *$ \\
\hline Gender (males, reference females) & 0.133 & 0.157 & $2.756^{* *}$ \\
\hline \multicolumn{4}{|l|}{ Age (reference $<18$ ) } \\
\hline $18-24$ & 0.153 & 0.289 & 1.847 \\
\hline $25-34$ & 0.094 & 0.345 & 1.322 \\
\hline $35-44$ & 0.044 & 0.461 & 0.737 \\
\hline $45-55$ & 0.090 & 0.528 & 1.688 \\
\hline $56<$ & 0.123 & 1.654 & 1.701 \\
\hline \multicolumn{4}{|l|}{ Nationality (reference Austria) } \\
\hline Finland & 0.015 & 0.183 & -0283 \\
\hline Greece & 0.094 & 0.200 & 1.705 \\
\hline H2: Entrepreneurial role model $\rightarrow$ Feasibility & 0.180 & 0.049 & $3.322 * *$ \\
\hline \multicolumn{4}{|l|}{ Control variables } \\
\hline Entrepreneurial experience & 0.182 & 0.269 & $3.331 * * *$ \\
\hline Gender (males, reference females) & 0.203 & 0.129 & $4.005 * * *$ \\
\hline \multicolumn{4}{|l|}{ Age (reference $<18$ ) } \\
\hline $18-24$ & -0.044 & 0.237 & -0.502 \\
\hline $25-34$ & 0.015 & 0.282 & 0.203 \\
\hline $35-44$ & 0.011 & 0.377 & 0.185 \\
\hline $45-55$ & 0.103 & 0.431 & 1.841 \\
\hline $56<$ & 0.214 & 1.352 & $2.843 * *$ \\
\hline \multicolumn{4}{|l|}{ Nationality (reference Austria) } \\
\hline Finland & -0.037 & 0.151 & -0.667 \\
\hline Greece & -0.205 & 0.164 & $-3.539 * * *$ \\
\hline
\end{tabular}

Notes: Standard error (SE), standardised regression weights (SRW); significance codes: $* * * p<0.001, * * p<0.01$. 
Figure 2 Results of the research models

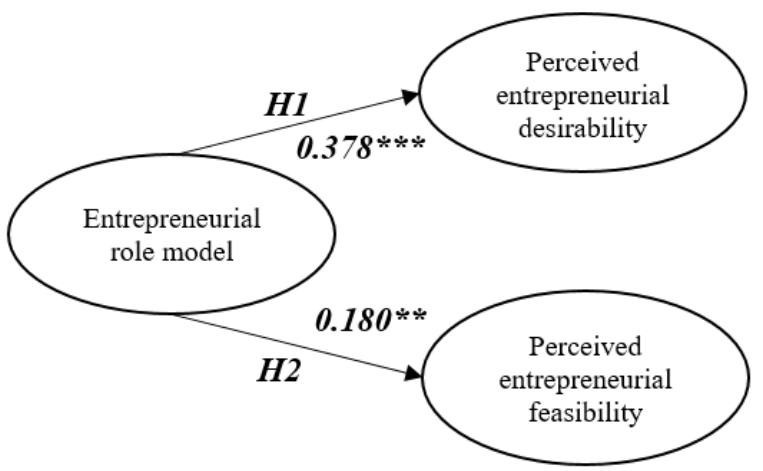

Notes: Standardised regression weights (SRW);

significance codes: $* * * p<0.001, * * p<0.01$.

\section{Discussion and conclusions}

The primary purpose of this work was to unravel the impact of exposure to entrepreneurial role models on entrepreneurial desirability and feasibility. To this end, a SEM was analysed to explore these effects. The present study builds on previous work such as Kolvereid (1996) and Tkachev and Kolvereid (1999), which developed the TPB [as originally proposed by Ajzen (1991)] further. Additionally, this study draws on social learning theory (Bandura, 1977; 1986) to confirm the significant impact on perceptions when observing entrepreneurial role models. The findings provide empirical support for the significant positive effect of exposure to entrepreneurial role models on both entrepreneurial desirability and feasibility. In general, the results suggest that observation of entrepreneurial role models stimulates entrepreneurial attitudes. In particular, this exposure shows great potential to impact entrepreneurial desirability and feasibility. However, entrepreneurial role model observation alone does not provide students with the necessary knowledge and skills to become a successful entrepreneur but rather serves as an additional ingredient for choosing the career path of an entrepreneur. These findings suggest a need for more engaged role models in EE. In enhancing understanding of the impact of entrepreneurial role models on entrepreneurial desirability and feasibility as potential drivers for nascent entrepreneurs, this study will help in developing further pedagogical instruments to promote entrepreneurial actions and long-term outcomes, with particular regard to sustainability and effective implementation.

\subsection{Theoretical and practical implications}

This contribution has some vital implications. First, it takes an in-depth look at the connection between entrepreneurial role models and entrepreneurial attitudes. Building on Ajzen's (1991) TPB and Bandura's (1977, 1986) social learning theory, the study extends current theory by discussing the power of entrepreneurial role models on entrepreneurial desirability and feasibility. Bandura's (1977) social learning theory postulates that individuals learn from each other via observation, imitation and modelling. Overall, our findings confirm that exposure to entrepreneurial models has a 
significant positive impact on the entrepreneurial attitudes to start a business. This approach can potentially be exploited on behalf of policymakers, in meeting both the economic requirements and the needs of $\mathrm{EE} \mathrm{-} \mathrm{an} \mathrm{idea} \mathrm{that} \mathrm{has} \mathrm{also} \mathrm{been} \mathrm{raised} \mathrm{by}$ Kolvereid and Isaksen (2006).

To empower entrepreneurial behaviour, EE initiatives at different educational institutions should engage role models to stimulate entrepreneurial desirability and feasibility for starting a business. In general, entrepreneurial role model exposure is a means of identifying promising entrepreneurs, and it may be useful for EE initiatives to incorporate entrepreneurial stories with other actions. In line with earlier recommendations (e.g., Van Auken et al., 2006), the present findings confirm that the innovative embedding of role models in EE can have a significant positive effect on those starting a business.

\subsection{Limitations and future research directions}

As with all academic endeavours, this study is subject to certain limitations. First, and most importantly, this study's sample was comprised of individuals from Austria, Finland and Greece. As a consequence, the findings of this investigation are dependent on cultural and present economic conditions in these countries and may not, therefore, be more widely generalisable. Further economic control variables might be useful to include, not least because Greece was enduring a crisis during the study period. In spite of these limitations, the study serves as a vital point of departure for future research.

The present findings suggest that future research should make further use of TPB-based models. As recommended by Cardon et al. (2013), each of the three domains of passion - inventing, founding and developing - suggest fruitful directions for future research. But a fine-grained examination of these specific objectives was beyond the scope of this study. This study also reiterates Fayolle et al.'s (2014) suggestion that EE research would benefit greatly from longitudinal data on the different factors in entrepreneurial intention, such as exposure to entrepreneurial role models. In this regard, validating all of the TPB variables as significant indirect predictors of entrepreneurial behaviour to entrepreneurial role models would further enrich the potential of the teaching potential of entrepreneurial role models. The present study needs to be repeated with larger samples and in different cultural settings, as well as with different EE target groups. In this regard, it would be interesting to explore how students at the primary level perceive entrepreneurial role models. Finally, given the observed results related to entrepreneurial desirability, future research should place more emphasis on how to increase the desirability of becoming an entrepreneur. This commitment appears crucial in light of the unexplored potential of future entrepreneurs; again, the present study serves as a fruitful point of departure in this regard.

\section{Acknowledgements}

The authors would like to thank the Austrian Science Fund FWF [J3740] for supporting this research project. The authors would like to express great appreciation to the following researchers for their assistance with the collection of the data: Prof. Helena Sjögrén, Prof. Nicos Komninos, Prof. Panagiotis Tsarchopoulos and Mag. 
Franz Stummer. Special thanks are extended to the entrepreneurs sharing their entrepreneurial lives with us.

\section{References}

Ajzen, I. (1991) 'The theory of planned behavior', Organizational Behavior And Human Decision Processes, Vol. 50, No. 2, pp.179-211.

Akerlof, G.A. and Kranton, R.E. (2000) 'Economics and identity', Quarterly Journal of Economics, Vol. 115, No. 3, pp.715-753.

Albornoz, C.A. (2008) 'Toward a set of trainable content on entrepreneurship education: a review of entrepreneurship research from an educational perspective', Journal of Technology Management \& Innovation, Vol. 3, No. 2, pp.86-98.

Allison, P. (1999) Multicollinearity in Logistic Regression, SAS Institute, Cary, NC.

Bae, T.J., Qian, S., Miao, C. and Fiet, J.O. (2014) 'The relationship between entrepreneurship education and entrepreneurial intentions: a meta-analytic review', Entrepreneurship: Theory \& Practice, Vol. 38, No. 2, pp.217-254.

Bagozzi, R.P. and Baumgartner, H. (1994) 'The evaluation of structural equation models and hypotheses testing’, in Bagozzi, R.P. (Ed.): Principles of Marketing Research, pp.386-422, Cambridge: Blackwell.

Bagozzi, R.P. and Yi, Y. (1988) 'On the evaluation of structural equation models', Journal of the Academy of Marketing Science, Vol. 16, No. 1, pp.74-94.

Bandura, A. (1977) 'Self-efficacy: toward a unifying theory of behavioral change', Psychological Review, Vol. 84, No. 2, p.191.

Bandura, A. (1986) Social Foundations of Thought and Action: A Social Cognitive Theory, Prentice-Hall, Englewood Cliffs, NJ.

Barling, J., Dupre, K.E. and Hepburn, C.G. (1998) 'Effects of parents' job insecurity on children's work beliefs and attitudes', Journal of Applied Psychology, Vol. 83, No. 1, p.112.

Bartlett, M. (1937) 'Properties of sufficiency and statistical tests', Proceedings of the Royal Statistical Society Series A, Vol. 160, pp.268-282.

Bentler, P.M. and Bonett, D.G. (1980) 'significance tests and goodness of fit in the analysis of covariance structures', Psychological Bulletin, Vol. 88, No. 3, pp.588-606.

Brush, C.G. (1992) 'Research on women business owners: past trends, a new perspective and future directions', Entrepreneurship: Theory \& Practice, Vol. 16, No. 4, pp.5-31.

Byrne, B.M. (1994) Structural Equation Modeling with Eqs and Eqs/Windows: Basic Concepts, Applications, and Programming, University of Ottawa, Sage, Canada.

Cardon, M.S., Gregoire, D.A., Stevens, C.E. and Patel, P.C. (2013) 'Measuring entrepreneurial passion: conceptual foundations and scale validation', Journal Of Business Venturing, Vol. 28, No. 3, pp.373-396.

Carmines, E.G. and Zeller, R.A. (1990) Reliability and Validity Assessment (Series: Quantitative Applications in the Social Sciences), Sage Publications, Newbury Park, CA.

Chen, C.C., Greene, P.G. and Crick, A. (1998) 'Does entrepreneurial self-efficacy distinguish entrepreneurs from managers?', Journal of Business Venturing, Vol. 13, No. 4, pp.295-316.

Chlosta, S., Patzelt, H., Klein, S.B. and Dormann, C. (2012) 'Parental role models and the decision to become self-employed: the moderating effect of personality', Small Business Economics, Vol. 38, No. 1, pp.121-138.

Clarke, J. (2011) 'Revitalizing entrepreneurship: how visual symbols are used in entrepreneurial performances', Journal Of Management Studies, Vol. 48, No. 6, pp.1365-1391.

Davidsson, P. and Wiklund, J. (1997) 'Values, beliefs and regional variations in new firm formation rates', Journal Of Economic Psychology, Vol. 18, No. 2, pp.179-199. 
Diaz-Garcia, C., Saez-Martinez, F. and Jimenez-Moreno, J. (2015) 'Assessing the impact of the 'entrepreneurs; education programme on participants' entrepreneurial intentions', Rusc-Universities and Knowledge Society Journal, Vol. 12, No. 3, pp.17-31.

Dziuban, C.D. and Shirkey, E.C. (1974) 'When is a correlation matrix appropriate for factor analysis? Some decision rules', Psychological Bulletin, Vol. 81, No. 6, pp.358-361.

EC (2013) Entrepreneurship 2020 Action Plan. Communication from the Commission to the European Parliament, the Council, the European Economic and Social Committee and the Committee of the Regions. Reigniting the Entrepreneurial Spirit in Europe, European Commission, Brussels.

Essers, C. and Benschop, Y. (2007) 'Enterprising identities: female entrepreneurs of Moroccan or Turkish origin in the Netherlands', Organization Studies, Vol. 28, No. 1, pp.49-69.

Falck, O., Heblich, S. and Luedemann, E. (2012) 'Identity and entrepreneurship: do school peers shape entrepreneurial intentions?', Small Business Economics, Vol. 39, No. 1, pp.39-59.

Fayolle, A., Gailly, B. and Lassas-Clerc, N. (2006) 'Assessing the impact of entrepreneurship education programmes: a new methodology', Journal of European Industrial Training, Vol. 30, Nos. 8/9, pp.701-720.

Fayolle, A., Liñán, F. and Moriano, J.A. (2014) 'Beyond entrepreneurial intentions: values and motivations in entrepreneurship', International Entrepreneurship and Management Journal, Vol. 10, No. 4, pp.679-689.

Fellnhofer, K. and Kraus, S. (2015) 'Examining attitudes towards entrepreneurship education: a comparative analysis among experts', International Journal of Entrepreneurial Venturing, Vol. 7, No. 4, pp.396-411.

Fellnhofer, K., Puumalainen, K. and Sjögrén, H. (2016) 'Entrepreneurial orientation and performance - are sexes equal?', International Journal of Entrepreneurial Behavior \& Research, Vol. 22, No. 3, pp.346-374.

Fernández-Pérez, V., García-Morales, V.J. and Pullés, D.C. (2016) 'Entrepreneurial decisionmaking, external social networks and strategic flexibility: the role of CEOs' cognition', European Management Journal, Vol. 34, No. 3, pp.296-309.

Fitzsimmons, J.R. and Douglas, E.J. (2011) 'Interaction between feasibility and desirability in the formation of entrepreneurial intentions', Journal of Business Venturing, Vol. 26, No. 4, pp.431-440.

Fornell, C. and Larcker, D.F. (1981) 'Structural equation models with unobservable variables and measurement error: algebra and statistics', Journal of Marketing Research, Vol. 18, No. 3, pp.382-388.

Fraenkel, J.R. and Wallen, N.E. (1993) How to Design and Evaluate Research in Education, McGraw-Hill, New York.

Giannetti, M. and Simonov, A. (2009) 'Social interactions and entrepreneurial activity', Journal of Economics \& Management Strategy, Vol. 18, No. 3, pp.665-709.

Gibson, D.E. (2004) 'Role models in career development: new directions for theory and research', Journal of Vocational Behavior, Vol. 65, No. 1, pp.134-156.

Guerrero, M., Rialp, J. and Urbano, D. (2008) 'The impact of desirability and feasibility on entrepreneurial intentions: a structural equation model', International Entrepreneurship and Management Journal, Vol. 4, No. 1, pp.35-50.

Hair, J.F., Anderson, R.E., Tatham, R.L. and Black, W.C. (1995) Multivariate Data Analyses with Readings, Prentice Hall College Div., NJ.

Hair, J.F., Black, B., Babin, B., Anderson, R.E. and Tatham, R.L. (2010) Multivariate Data Analysis, 7th ed., Prentice Hall, Upper Saddle River, NJ.

Holtz-Eakin, D. (2000) 'Public policy toward entrepreneurship', Small Business Economics, Vol. 15, No. 4, pp.283-291.

Hu, L.T. and Bentler, P.M. (1999) 'Cutoff criteria for fit indexes in covariance structure analysis: conventional criteria versus new alternatives', Structural Equation Modeling: A Multidisciplinary Journal, Vol. 6, No. 1, pp.1-55. 
Kaiser, H.F. (1974) ‘An index of factorial simplicity’, Psychometrika, Vol. 39, No. 1, pp.31-36.

Kibler, E., Kautonen, T. and Fink, M. (2014) 'Regional social legitimacy of entrepreneurship: implications for entrepreneurial intention and start-up behaviour', Regional Studies, Vol. 48, No. 6, pp.995-1015.

Koellinger, P., Minniti, M. and Schade, C. (2007) 'I Think I Can, I Think I Can': overconfidence and entrepreneurial behavior', Journal Of Economic Psychology, Vol. 28, No. 4, pp.502-527.

Kolvereid, L. (1996) Prediction of Employment Status Choice Intentions, Working Paper Series, Henley Management College HWP, Henley.

Kolvereid, L. and Isaksen, E. (2006) 'New business start-up and subsequent entry into selfemployment', Journal of Business Venturing, Vol. 21, No. 6, pp.866-885.

Krueger Jr, N.F., Reilly, M.D. and Carsrud, A.L. (2000) 'Competing models of entrepreneurial intentions', Journal of Business Venturing, Vol. 15, No. 5, pp.411-432.

Krueger, N. (1993) 'The impact of prior entrepreneurial exposure on perceptions of new venture feasibility and desirability', Entrepreneurship: Theory \& Practice, Vol. 18, No. 1, pp.5-21.

Krueger, N. and Brazeal, P. (1994) 'Entrepreneurial potential \& potential entrepreneurs', Entrepreneurship Theory \& Practice, Vol. 18, No. 3, pp.91-104.

Krueger, N.F., Reilly, M.D. and Carsrud, A.L. (2000) 'Competing models of entrepreneurial intentions', Journal of Business Venturing, Vol. 15, No. 5, pp.411-432.

Krumboltz, J.D., Mitchell, A.M. and Jones, G.B. (1976) 'A social learning theory of career selection', The Counseling Psychologist, Vol. 6, No. 1, pp.71-81.

Kuehn, K.W. (2008) 'Entrepreneurial intentions research: implications for entrepreneurship education', Journal Of Entrepreneurship Education, Vol. 11, No., pp.87-98.

Lerner, M., Brush, C. and Hisrich, R. (1997) 'Israeli women entrepreneurs: an examination of factors affecting performance', Journal of Business Venturing, Vol. 12, No. 4, pp.315-339.

Letz, R. and Gerr, F. (1995) 'Standing steadiness measurements: empirical selection of testing protocol and outcome measures', Neurotoxicology and Teratology, Vol. 17, No. 6, pp.611-616.

Levesque, M. and Minniti, M. (2006) 'The effect of aging on entrepreneurial behavior', Journal Of Business Venturing, Vol. 21, No. 2, pp.177-194.

López, X., Valenzuela, J., Nussbaum, M. and Tsai, C-C. (2015) 'Some recommendations for the reporting of quantitative studies', Computers \& Education, Vol. 91, No. C, pp.106-110.

Lorz, M., Mueller, S. and Volery, T. (2013) 'Entrepreneurship education: a systematic review of the methods in impact studies', Journal of Enterprising Culture, Vol. 21, No. 2, pp.123-151.

MacCallum, R.C., Browne, M.W. and Sugawara, H.M. (1996) 'Power analysis and determination of sample size for covariance structure modeling', Psychological Methods, Vol. 1, No. 2, p.130.

Mason, J. and Siqueira, A.C.O. (2014) 'Addressing the challenges of future entrepreneurship education: an assessment of textbooks for teaching entrepreneurship', in Hoskinson, S. and Kuratko, D.F. (Eds.): Innovative Pathways for University Entrepreneurship in the 21st Century, pp.41-64, Emerald Group Publishing Ltd, Bingley.

Matthews, C.H. and Moser, S.B. (1996) 'A longitudinal investigation of the impact of family background and gender on interest in small firm ownership', Journal of Small Business Management, Vol. 34, No. 2, p.29.

McDougall, P., Robinson, J.R. and DeNisi, A. (1992) 'Modeling new venture performance: an analysis of new venture strategy, industry structure and venture origin', Journal of Business Venturing, Vol. 7, No. 4, pp.267-289.

Mitchell, L.K. and Krumboltz, J.D. (1984) Career Choice and Development: Applying Contemporary Theory to Practice, Jossey-Bass, San Francisco, CA.

Moghavvemi, S. and Noor Akma Mohd, S. (2014) 'Malaysian entrepreneurs propensity to use it innovation', Journal of Enterprise Information Management, Vol. 27, No. 2, pp.139-157. 
Mulaik, S.A., James, L.R., Van Alstine, J., Bennett, N., Lind, S. and Stilwell, C.D. (1989) 'Evaluation of goodness-of-fit indices for structural equation models', Psychological Bulletin, Vol. 105, No. 3, pp.430-445.

Murphy, K.R. and Davidshofer, C.O. (1988) Psychological Testing, Prentice-Hall, New Jersey.

Mwasalwiba, E.S. (2010) 'Entrepreneurship education: a review of its objectives, teaching methods, and impact indicators', Education+ Training, Vol. 52, No. 1, pp.20-47.

Nanda, R. and Sørensen, J.B. (2010) 'Workplace peers and entrepreneurship', Management Science, Vol. 56, No. 7, pp.1116-1126.

Nauta, M.M. and Kokaly, M.L. (2001) 'Assessing role model influences on students' academic and vocational decisions', Journal of Career Assessment, Vol. 9, No. 1, pp.81-99.

Nunnally, J. (1978) Psychometric Theory, McGraw-Hill, New York.

Obschonka, M., Goethner, M., Silbereisen, R.K. and Cantner, U. (2012) 'Social identity and the transition to entrepreneurship: the role of group identification with workplace peers', Journal of Vocational Behavior, Vol. 80, No. 1, pp.137-147.

Oosterbeek, H., Van Praag, M. and Ijsselstein, A. (2010) 'The impact of entrepreneurship education on entrepreneurship skills and motivation', European Economic Review, Vol. 54, No. 3, pp.442-454.

Peterman, N.E. and Kennedy, J. (2003) 'Enterprise education: influencing students' perceptions of entrepreneurship', Entrepreneurship: Theory \& Practice, Vol. 28, No. 2, pp.129-144.

Pittaway, L. and Cope, J. (2007) 'Entrepreneurship education: a systematic review of the evidence', International Small Business Journal, Vol. 25, No. 5, pp.479-510.

Rasmussen, E. (2011) 'Book review: entrepreneurship education', International Small Business Journal, Vol. 29, No. 6, pp.731-733.

Raykov, T. (1997) 'Estimation of composite reliability for congeneric measures', Applied Psychological Measurement, Vol. 21, No. 2, pp.173-184.

Reio, T.G. (2010) 'The threat of common method variance bias to theory building', Human Resource Development Review, Vol. 9, No. 4, pp.405-411.

Rideout, E.C. and Gray, D.O. (2013) 'Does entrepreneurship education really work? A review and methodological critique of the empirical literature on the effects of university-based entrepreneurship education', Journal of Small Business Management, Vol. 51, No. 3, pp.329-351.

Saeed, S., Muffatto, M. and Yousafzai, S.Y. (2014) 'Exploring intergenerational influence on entrepreneurial intention: the mediating role of perceived desirability and perceived feasibility', International Journal of Entrepreneurship \& Innovation Management, Vol. 18, Nos. 2/3, pp.134-153.

Scherer, R., Adams, J. and Wiebe, F. (1989) 'Developing entrepreneurial behaviors: a social learning theory perspective', Journal of Organizational Change Management, Vol. 2, No. 3, pp.16-28.

Scherer, R.F., Brodzinski, J.D. and Wiebe, F. (1991) 'Examining the relationship between personality and entrepreneurial career preference 1', Entrepreneurship \& Regional Development, Vol. 3, No. 2, pp.195-206.

Schreiber, J.B., Nora, A., Stage, F.K., Barlow, E.A. and King, J. (2006) 'Reporting structural equation modeling and confirmatory factor analysis results: a review', The Journal of Educational Research, Vol. 99, No. 6, pp.323-338.

Schröder, E. and Schmitt-Rodermund, E. (2006) 'Crystallizing enterprising interests among adolescents through a career development program: the role of personality and family background', Journal of Vocational Behavior, Vol. 69, No. 3, pp.494-509.

Schumpeter, J.A. (1934) The Theory of Economic Development: An Inquiry into Profits, Capital, Credit, Interest, and the Business Cycle, Harvard University Press, Cambridge.

Shane, S. and Venkataraman, S. (2000) 'The promise of entrepreneurship as a field of research', Academy of Management Review, Vol. 25, No. 1, pp.217-226. 
Shapero, A. and Sokol, L. (1982) 'The social dimensions of entrepreneurship', in Kent, C.A., Sexton, D.L. and Vesper, K.H. (Eds.): Encyclopedia of Entrepreneurship, pp.72-90, Prentice-Hall, New York: Englewood Cliffs, NJ.

Souitaris, V., Zerbinati, S. and Al-Laham, A. (2007) 'Do entrepreneurship programmes raise entrepreneurial intention of science and engineering students? The effect of learning, inspiration and resources', Journal of Business Venturing, Vol. 22, No. 4, pp.566-591.

Steiger, J.H. (2007) 'Understanding the limitations of global fit assessment in structural equation modeling', Personality and Individual Differences, Vol. 42, No. 5, pp.893-898.

Stuart, T.E. and Ding, W.W. (2006) 'When do scientists become entrepreneurs? The social structural antecedents of commercial activity in the academic life sciences', American Journal of Sociology, Vol. 112, No. 1, pp.97-144.

Tkachev, A. and Kolvereid, L. (1999) 'Self-employment intentions among russian students', Entrepreneurship \& Regional Development, Vol. 11, No. 3, pp.269-280.

Van Auken, H., Fry, F.L. and Stephens, P. (2006) 'The influence of role models on entrepreneurial intentions', Journal of Developmental Entrepreneurship, Vol. 11, No. 02, pp.157-167.

Wry, T., Lounsbury, M. and Glynn, M.A. (2011) 'Legitimating nascent collective identities: coordinating cultural entrepreneurship', Organization Science, Vol. 22, No. 2, pp.449-463.

Zapkau, F.B., Schwens, C., Steinmetz, H. and Kabst, R. (2015) 'Disentangling the effect of prior entrepreneurial exposure on entrepreneurial intention', Journal of Business Research, Vol. 68, No. 3, pp.639-653. 


\section{Appendix}

Table 5 Entrepreneurial role model - inspiration/modelling

\begin{tabular}{llcccc}
\hline Domain & \multicolumn{1}{c}{ Item } & Mean & SD & $\begin{array}{c}\text { Item total } \\
\text { correlation }\end{array}$ & $\begin{array}{c}\text { Alpha if } \\
\text { item is } \\
\text { deleted }\end{array}$ \\
\hline IM_01 & $\begin{array}{l}\text { There is an entrepreneurial person I am trying } \\
\text { to be like in my career pursuits }\end{array}$ & 4.15 & 1.64 & .717 & .818 \\
IM_02 & $\begin{array}{l}\text { There is an entrepreneurial person particularly } \\
\text { inspirational to me in my career path }\end{array}$ & 4.15 & 1.63 & .771 & .804 \\
IM_03 & $\begin{array}{l}\text { In the career path I am pursuing, there is an } \\
\text { entrepreneurial person I admire }\end{array}$ & 4.25 & 1.59 & .724 & .817 \\
IM_04 & $\begin{array}{l}\text { I have a mentor in my potential entrepreneurial } \\
\text { career field }\end{array}$ & 3.36 & 1.67 & .528 & .866 \\
IM_05 & $\begin{array}{l}\text { I know of an entrepreneurial person who has a } \\
\text { career I would like to pursue }\end{array}$ & 4.18 & 1.69 & .646 & .837 \\
\hline
\end{tabular}

Note: Participants evaluated the statements from 1 (strongly disagree) to

7 (strongly agree)

Source: Modified from Nauta and Kokaly (2001)

Table 6 Perceived entrepreneurial desirability

\begin{tabular}{llcccc}
\hline Domain & Item & Mean & SD & $\begin{array}{c}\text { Item total } \\
\text { correlation }\end{array}$ & $\begin{array}{c}\text { Alpha if } \\
\text { item is } \\
\text { deleted }\end{array}$ \\
\hline D_1 & I would love to start my own business & 4.43 & 1.76 & .804 & .784 \\
D_2 & I would be very tense to start my own business & 4.45 & 1.56 & .685 & .889 \\
D_3 & $\begin{array}{l}\text { I would be very enthusiastic to start my own } \\
\text { business }\end{array}$ & 4.55 & 1.66 & .801 & .787 \\
\hline
\end{tabular}

Note: Participants evaluated the statements from 1 (strongly disagree) to 7 (strongly agree)

Source: Modified from Peterman and Kennedy (2003)

Table 7 Perceived entrepreneurial feasibility

\begin{tabular}{llcccc}
\hline Domain & Item & Mean & SD & $\begin{array}{c}\text { Item total } \\
\text { correlation }\end{array}$ & $\begin{array}{c}\text { Alpha if } \\
\text { item is } \\
\text { deleted }\end{array}$ \\
\hline F_1 & It will be easy to start my own business & 2.81 & 1.55 & .626 & .722 \\
F_2 & $\begin{array}{l}\text { I will be successful when I have my own } \\
\text { business }\end{array}$ & 4.33 & 1.41 & .553 & .747 \\
F_3 & $\begin{array}{l}\text { I won't be overworked when I have my own } \\
\text { business }\end{array}$ & 3.31 & 1.63 & .541 & .750 \\
& F_4 & & & & .7 .11 \\
F_5 & I know enough how to start a business & 4.77 & 1.62 & .456 & .778 \\
\hline
\end{tabular}

Note: Participants evaluated the statements from 1 (strongly disagree) to

7 (strongly agree)

Source: Modified from Peterman and Kennedy (2003) 
Table 8 Results of a confirmatory factor analysis (CFA)

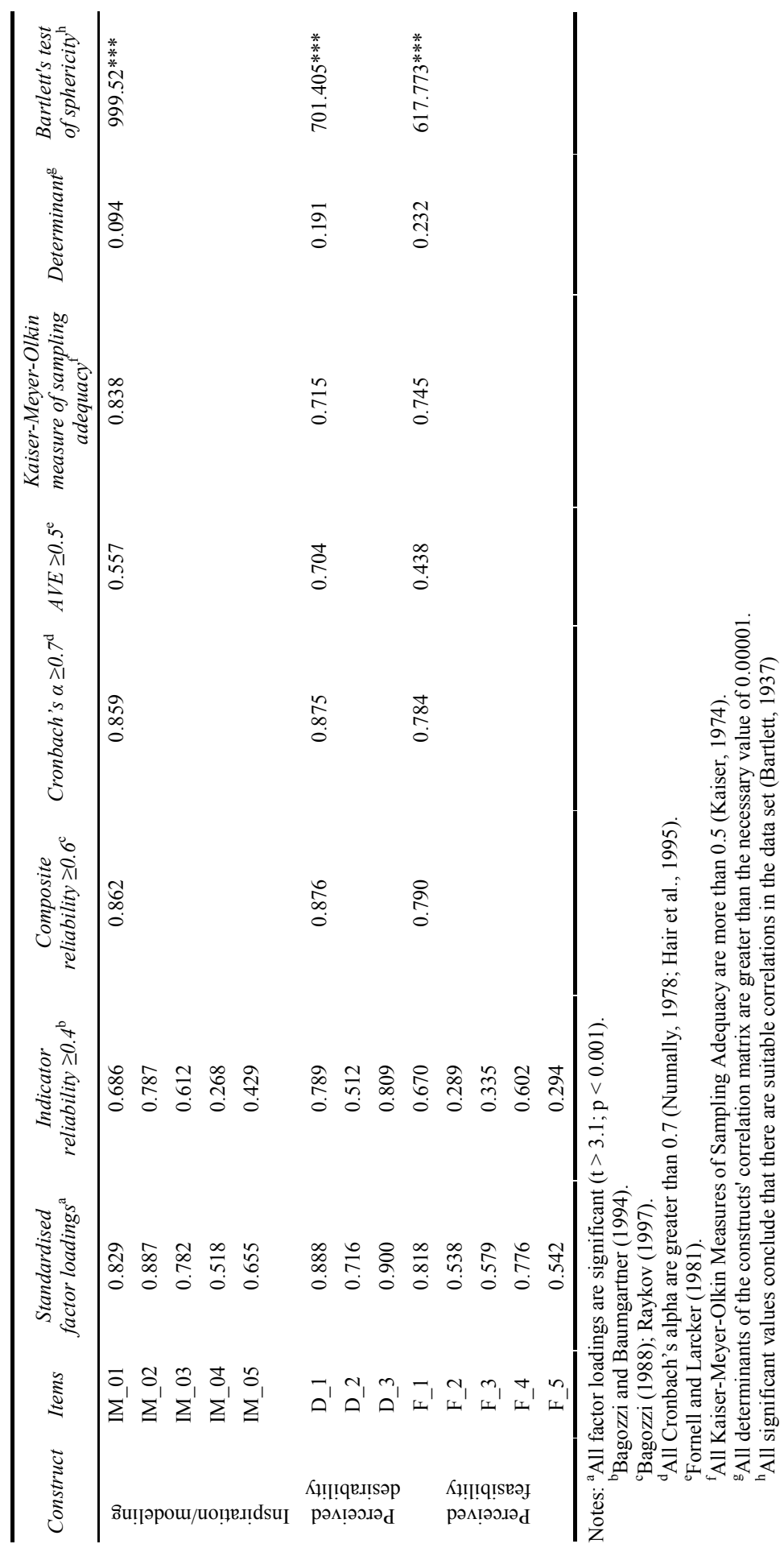

